\title{
EL CASTIGO DE CEGAR A UN REO
}

\author{
BARBÓN GARCÍA JJ ${ }^{1}$
}

Se denominan Beatos a una treintena de manuscritos, realizados entre los s. IX al XIII, que nos transmiten los Comentarios del Apocalipsis de Beato de Liébana, abad del monasterio cántabro de San Martín de Turieno (el actual de Santo Toribio) y que fue redactado en el año 776 para oponerse a la herejía del adopcionismo, que defendía el origen exclusivamente humano de Cristo. Sin embargo, la verdadera fama de los Beatos se debe a sus ricas y elaboradas ilustraciones, que constituyen una de las manifestaciones artísticas más interesantes de la

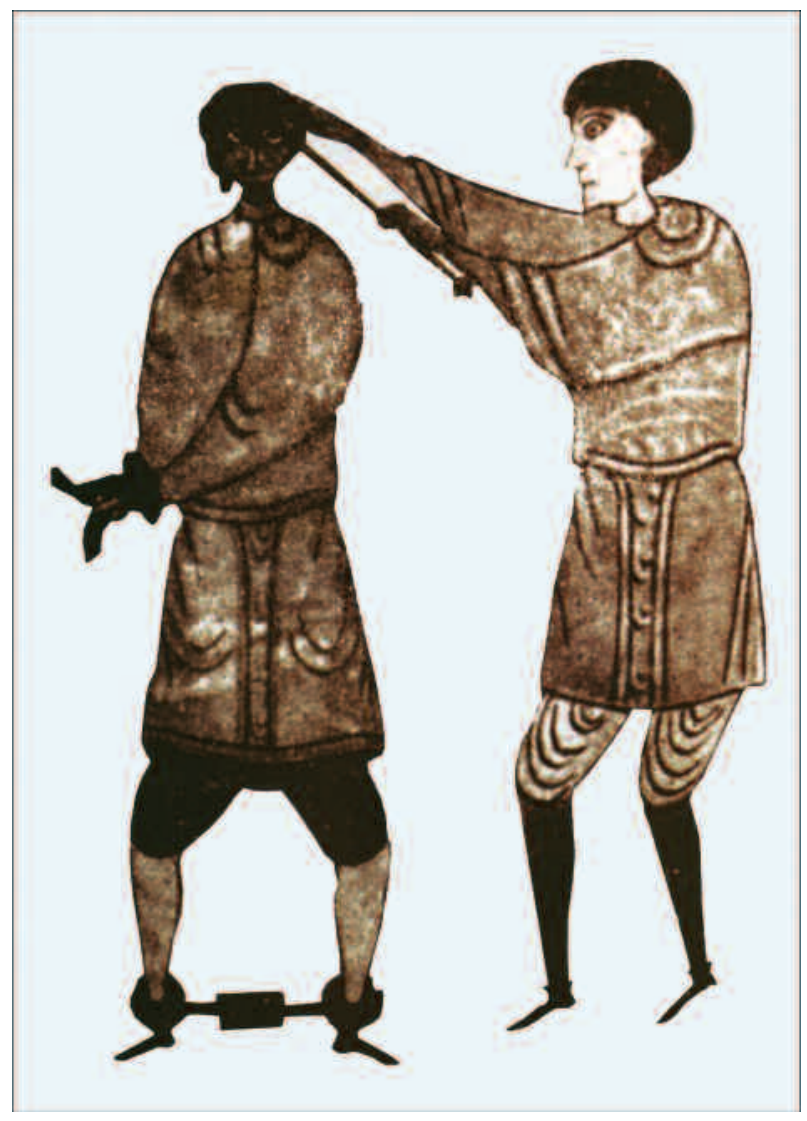

Códice visigótico.
Edad Media y representan la madurez de la miniatura hispánica. El escribano copiaba primero el texto del manuscrito, palabra por palabra, dejando los espacios donde el miniaturista añadía posteriormente las imágenes. La iconografía responde con sus formas románicas, planas y lineales, a la explicación del texto religioso, aunque algunas miniaturas se permiten recrear escenas de la vida medieval.

El más antiguo y célebre de los Beatos fue iluminado por el monje Magio, Magius o Maius por encargo del abad del Monasterio de San Miguel de

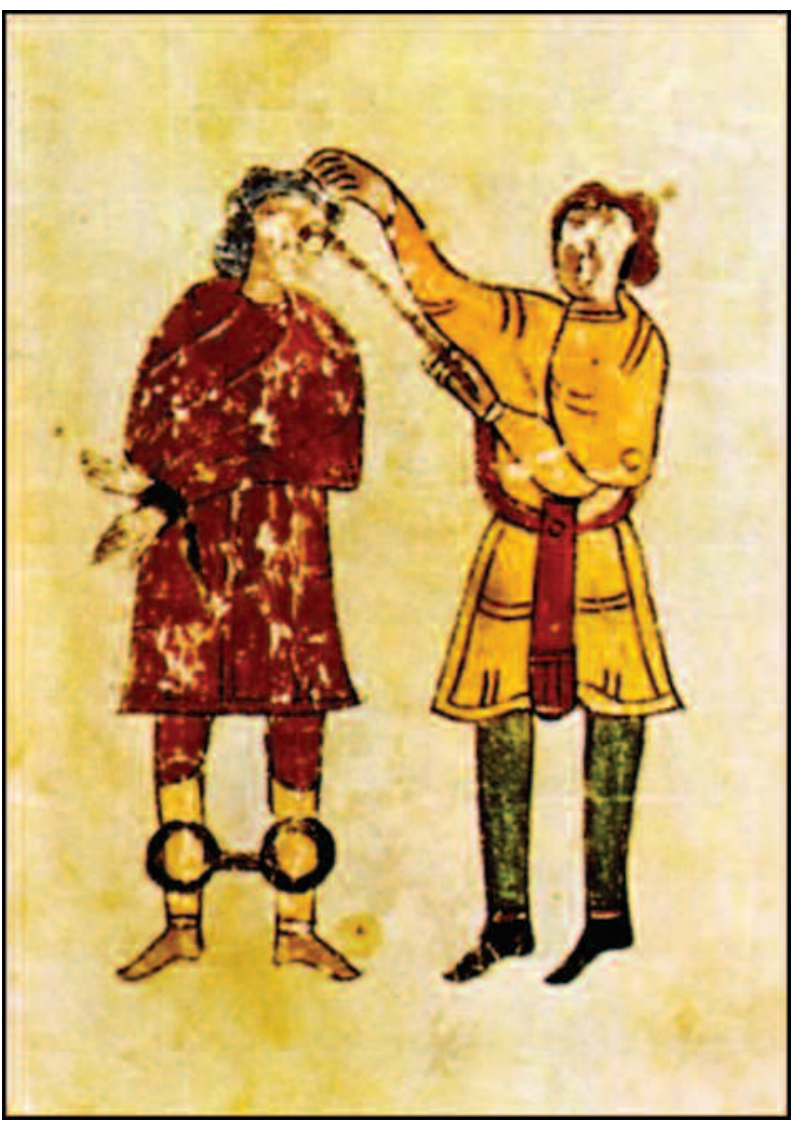

Morgan Beatus.

\footnotetext{
1 Doctor en Medicina. Hospital San Agustín de Avilés. Asturias. España. E-mail: jjbarbon@telecable.es
} 
Escalada (León) a mediados del s. X (Pierpont Morgan Library de Nueva York), y es el códice que marcará el tipo de ilustración de los demás Comentarios al Apocalipsis. Este códice del Beato de San Miguel de Escalada o Morgan Beatus, en el que se recoge este castigo de cegamiento con hierros candentes, desaparecerá en 1837, durante la desamortización de los bienes de la Iglesia y tras pasar por varios coleccionistas de manuscritos fue adquirido por la Biblioteca Pierpont Morgan en 1919.

A lo largo de la Historia de España son múltiples los ejemplos de este bárbaro castigo que incluso estaba recogido como ley en el Liber Iudiciorum de los visigodos, para aquellos que atentaban contra el príncipe. Así tanto en la Hispania Visigoda como durante la Reconquista existen multitud de ejemplos donde el castigo de ceguera se aplicaba a vencidos que desafiaban el poder del rey o para eliminar candidatos al trono.

\section{BIBLIOGRAFÍA}

- de Silva y Verástegui S. Los beatos. In: Cuadernos de Arte Español. Historia 16 (100): Madrid; 1991.

- Arruga A. La mutilación deliberada de los Ojos. Arch Soc Esp Oftalmol 2003; 78: 339-340.

- Rodríguez Muñoz J. La monarquía asturiana. Oviedo: Ed. Prensa Asturiana; 2004. 